\title{
(Un)translatability of culture-bound elements in AVT
}

\begin{abstract}
The author focuses on two modes of audiovisual translation - dubbing and voice-over. The aim of this paper is to dispel the myth of absolute cultural non-translatability, and excerpts from films about super heroes are examined to this purpose. An audiovisual translator faces many challenges, and translation strategies for texts characterised by cultural elements are not only helpful but indispensable in facilitating the translation process. One such strategy is adaptation, which proves to be highly effective and contributes to the positive reception of films by their intended viewers. The correct interpretation of the cultural fragments determines the accessibility of the language and can contribute to enhancing the humorous effect in the Polish language version. The analyzed movie excerpts demonstrate that the Polish versions contain creative and sometimes unexpected translational ideas for adapting the source-culture elements to the target culture, resulting in dialogue that is appreciated by Polish viewers.
\end{abstract}

Keywords: untranslatability, source culture, target culture, AVT, adaptation

\section{Introduction}

In today's fast-growing and technologically advanced world there are over 7000 languages. Thus, it seems as no surprise that there is a strong need to overcome language barriers in order to communicate, to acknowledge different cultures and expand people's horizons. What should the first step be to accomplish this demanding and ambitious goal? The ideal solution would be to build a bridge between languages and cultures and this is the time to point to translation as an academic discipline. Translation is indispensable to communicate cultures and to make the industrious world prosperous. Undeniable, the movie industry 
would not be booming but for audiovisual translators who bring, communicate a film to a wider audience.

Films have evolved and with the introduction of sound in 1930s, new genres such as action, musicals, documentaries, social statement films, comedies, westerns, and horror movies were created. Today the list is much longer and amounts to over twenty different film types.

Every genre causes difficulties when it comes to translation but for the purpose of this article only fantasy, superhero movies are to be analyzed. Putting aside the linguistic aspects of the texts, the intention is to demonstrate that there are culture-bound elements in the source language (SL), which are generally perceived as difficult or even impossible to translate, but they make the film unique and funnier. For this reason, the method of rendering the selected examples of source culture (SC) is tremendously important for the overall effect of the movie. It is also worth highlighting that out of three main audiovisual translation (AVT) modes, only dubbing and voice-over are examined as a precise form of rendering the original. For the analysis, four different superhero films have been chosen, i.e. Thor: Ragnarok (2017), DVD - dubbing: Jakub Wecsile, Waldemar Modestowicz; Green Lantern (2011), Netflix - dubbing: Adam Kurzak and Wojciech Kaczmarski, The Amazing Spider-Man (2012), Netflix - dubbing: Anna Niedźwiedzka and Anna Apostolakis-Gluzińska; Deadpool (2016), cda ${ }^{1}$ - voice-over: Studio Sonica.

\section{The concept of untranslatability}

There are numerous differences between languages, which is why a translation process is a complex task. According to Olgierd Wojtasiewicz $(1957)^{2}$, a translator and a linguist, there are causes of untranslatability among which there are technical terms (names of plants and animals, borrowings, local phenomena, geographical terms, weather terms, currency units, local measurements, etc.), allusions, symbols and dialects. He realized that cultural differences were more problematic to render than structural differences between languages, hence his concept of untranslatability is still valuable for translation studies.

Krzysztof Hejwowski $(2009)^{3}$ also sees the difficulties when translating culture-bound elements but he disagrees with the statement that source texts (ST) that abound in evident examples of SC are simply impossible to render into a target language (TL). Instead, he believes that a recipient of the target text (TT) will never have identical emotions toward the text $\mathrm{s} / \mathrm{he}$ is being exposed to as it is impossible to recreate identical feeling of the ST. Not to leave a translator on their own, Hejwowski writes that there are methods to translate culture-bounds elements which are to facilitate the process and dissolve doubts as what to do with a problematic cultural element.

\footnotetext{
${ }^{1}$ https://www.cda.pl/video/380312824 [access: 20.09.2021].

2 Wojtasiewicz O., 1957, Wstęp do teorii tlumaczenia, Wrocław: Zakład Imienia Ossolińskich.

3 Hejwowski K., 2009, Kognitywno-komunikacyjna teoria przekładu, Warszawa: PWN.
} 


\section{Translation strategies}

Jean-Paul Vinay and Jean Darbelnet $(2000)^{4}$ propose seven methods to render culture-bound elements. The translation techniques that they advocate can be applied at the linguistic levels of lexis, grammar and text. These are: borrowing, calque, literal translation, transposition, modulation, equivalence, adaptation.

A translator tends to use borrowing when there is no lexical equivalent for a word in SL. In this case, s/he takes the SL form into the TL. According to Vinay and Darbelnet, one aim of this technique is "to create a stylistic effect"5. For others, this technique is essential to maintain the specific and unique character of a text as well as to convey a sound effect. Of course, some forms of explanation can be added to assist the receiver who is not familiarized with a foreign term. A similar situation is with retaining brand names. Companies usually decide not to translate the name of the product due to the difficulties in finding the proper sounds and connotations. French government, for instance, has taken certain actions to de-americanize their language.

The next technique, the calque, is a literal translation of a phrase in a SL into a phrase in a TL. Calques are used in many translations, especially when a translator cannot find another word in a target language to render the original meaning and a sense of a word.

Literal translation refers to what its name suggests. While changing a text from a SL to a TL, a translator does not alter anything apart from the changes that are required by the TL grammar.

Transposition is a technique dealing with grammatical changes in translation. In certain cases, it is crucial for the correct meaning of the text to change the category of a word in a sentence. The difference is significant, especially in the reception of the text by the receiver.

Vinay and Darbelnet define the next technique, modulation, as "a variation in the message, obtained by changing the point of view, lighting"6. Modulation requires general knowledge of the TL and it obliges the translator to be qualified and experienced. "A modulation may take place between such things as an abstract and a concrete term, between a part and a whole, or it may reverse a point of view"?

The last but one technique, equivalence, is explained as "the translation of idioms when two languages refer to the same situation in totally different ways" "It is not an easy task for a translator to learn all idioms in a foreign language, especially when s/he does not use them very often. The task gets even more problematic when a dictionary fails to provide the translator with a proper meaning of an idiom. Of course, a receiver may find this translation funny and not entirely understandable due to the fact that it was translated

\footnotetext{
${ }^{4}$ Vinay J. and Darbelnet J., 2000, Stylistique comparée du français et de l'anglais. Méthode de traduction (Comparative Stylistics of French and English. Methodology for Translation), Paris: Didier, p. 47-50.

5 Ibidem.

${ }^{6}$ Ibidem, p. 51.

7 Fawcett P., 1997, Translation and Language: Linguistic Theories Explained, Manchester, UK: St. Jerome Publishing, p. 37.

8 Ibidem, p. 38.
} 
not as an idiom. This mistake is called 'overtranslation'. The relevant aspect in translating idioms is to find them and find a similar idiom in a TL or, if it does not exist, to replace it with a phrase that would evoke similar emotions and have the same impact on a receiver.

The last translation technique listed by Vinay and Darbelnet is adaptation. It is "supposed to take place when the receiving culture has little or nothing in its experience that would allow it to understand a close translation". In this case, a translator should change the source language so that it fits the target culture. In this method, the most essential thing is to make a receiver fully understand the translation. It sometimes entails certain changes in the language but a translator implements them to succeed.

For the purpose of this article the main emphasis is put on the last strategy - adaptation which demonstrates the most vivid discrepancies between ST and TT.

\section{Culture-bound elements in AVT of superhero movies}

When a film mainly serves to entertain, it usually entails certain dose of humor which is welcome by the viewers but problematic for an AV translator. The translator has a few linguistic choices to make a TT as similar as possible to a ST but the attention should be shifted to a target culture in order to make a target viewer laugh and feel more involved in the film. The examples below are to demonstrate the difference between the ST and the TT and how it contributes to the final effect of the translation. The adaptation is to be used as a comparative criterion.

Thor: Ragnarok is the first film to be analyzed. The scene takes place in London and Doctor Strange is asking Thor.

\begin{tabular}{|c|c|}
\hline ST $(00: 15: 55-00: 16: 01)^{10}$ & TT \\
\hline $\begin{array}{c}\text { Doctor Strange: Take a sit. } \\
\text { Tea? }\end{array}$ & $\begin{array}{c}\text { Doktor Strange: Klapnij sobie. } \\
\text { Kawki? }\end{array}$ \\
\hline Thor: I don't drink tea. & Thor: Nie pijam kawy. \\
\hline
\end{tabular}

The interesting change refers to the drink. In the original we have "tea" which falls into the pattern of English five o'clock tea. Both Doctor Strange and Thor are in London and afternoon tea is an old British tradition of having tea between 3 and 5 o'clock in the afternoon. Nevertheless, in Poland coffee is gaining a popularity, especially when it comes to social meetings. Since $1964^{11}$ coffee has become a part of every office life and it has a lot of enthusiasts. As a result, employing "coffee" instead of a "tea" is not only a good decision but also a proof that a translator moves with the times. Adopting this translation could set a new trend in rendering texts when the main attention is focused only on the target viewer, to make him/ her fully understand the scene and the screen reality.

\footnotetext{
9 Ibidem, p. 39.

10 hh:mm:ss.

${ }^{11}$ https://pl.wikipedia.org/wiki/Kawa\#Kawa_w_Polsce [access: 19.09.2021].
} 
Another scene refers to a situation when Thor is trying to identify himself. There is a special voice detector on an aircraft and after a few tries, Thor, exasperated, finally succeeds. The right voice command is:

\begin{tabular}{|l|l|}
\hline ST $(01: 11: 12)$ & TT \\
\hline Point Break & Blond Młot \\
\hline
\end{tabular}

This scene is humorous as Thor, god of thunder, expects to gain the access by saying "The strongest avenger", instead the right command is "Point Break" which is a movie from 1991 telling a story of a Californian gang of bank robbers who are also surfers. ${ }^{12}$ One of the characters, played by Partick Swayze, has long, curly, blond hair, which matches Thor's appearance. But simultaneously "Point Break" makes him feel silly and unappreciated. The equivalent expression, "Blond Młot", is an example of adopting the original title and creating something different, ambiguous and equally successful. Not only does "Młot" denote an idiotic person but also it refers to Thor's main weapon - hammer that is the essence of his power. Adaptation made the TT equally funny and accessible to a target viewer.

The last scene discussed in the film is the conversation between Grandmaster and Topaz, his right hand.

\begin{tabular}{|c|c|}
\hline ST $(01: 24: 21-01: 24: 40)$ & TT \\
\hline Grandmaster: Revolution? & Grandmaster: Rewolucja? \\
\hline How did it happen? & Jak to możliwe? \\
\hline Topaz: Don't know. & Topaz: Cholera wie. \\
\hline But the arena's mainframe & Ale główny computer \\
\hline for the obedience discs & nadzorujący czipy \\
\hline have been deactivated & został wyłączony \\
\hline and the slaves have armed themselves. & a niewolnicy zdobyli broń palną. \\
\hline Grandmaster: Oh. I don't like that word. & Grandmaster: Oj nie. Nie lubię tego słowa. \\
\hline Topaz: Which? Mainframe? & Topaz: Którego? Komputer? \\
\hline$[\ldots]$ & {$[\ldots]$} \\
\hline $\begin{array}{l}\text { Sorry, the prisoners with jobs } \\
\text { have armed themselves. }\end{array}$ & $\begin{array}{l}\text { No tak. Pracownicy bezetatowi } \\
\text { zdobyli broń palną. }\end{array}$ \\
\hline
\end{tabular}

The interesting juxtaposition is the original phrase "the prisoners with jobs" and its dubbed version "pracownicy bezetatowi". The original "slaves" were replaced with "prisoners", whereas the target viewer hears "pracownicy". The line in the SL is closer in meaning, thus lexically more coherent but the translation is funnier and has its roots in the TC as, contrary to a contract of employment, the worst contracts are a contract to perform a specified task and a contract for specific work. As a result, people who are

\footnotetext{
12 https://www.imdb.com/title/tt0102685/ [access: 19.09.2021].
} 
under one of the two contracts may feel exploited, which matches the sense of the line. This example also proves that by adapting the SC into the $\mathrm{TC}$, the viewer does not miss a thing and as a bonus $\mathrm{s} /$ he receives even funnier dialogues.

Another superhero film, Green Lantern, does not contain a lot of examples of adaptation, thus in comparison to Thor, it seems less funny. Nevertheless, at the beginning of the movie there is a scene when one of the officers is apologizing to the scientist for causing inconvenience.

\begin{tabular}{|l|l|}
\hline ST $(00: 28: 22-00: 28: 25)$ & TT \\
\hline $\begin{array}{l}\text { I must apologize for the theatrics, } \\
\text { but the government does like its protocols. }\end{array}$ & $\begin{array}{l}\text { Przepraszam za tę ciuciubabkę, } \\
\text { lecz obowiązują nas regulaminy. }\end{array}$ \\
\hline
\end{tabular}

The original noun "theatrics" refers to "behavior that is intended to get attention"13. This corresponds to what happens in the movie. The government wishes to keep confidential the fact that an autopsy is going to be carried out on the alien. Therefore, the officials implement all necessary procedures to keep the public in the dark. The Polish equivalent "ciuciubabka" is "a children's game [popular in Poland] in which one person has a cloth tied over their eyes and tries to catch the others"14. The purpose of the game is to make the hoodman confused, which exactly mirrors the original scene. Consequently, the translator proves that the main attention is focused on the target viewer and TC.

In the next movie, The Amazing Spider-Man, a viewer watches a scene where the hungry spider-man is relishing his dinner. He is praising his aunt by saying:

\begin{tabular}{|l|l|}
\hline ST $(00: 25: 38-00: 25: 40)$ & TT \\
\hline This is your meat loaf. & To jest ten twój pasztet. \\
This beats all other meat loafs. & Najlepszy pasztet świata. \\
\hline
\end{tabular}

The translator could have been tempted to employ more popular Polish counterpart "pieczeń rzymska"15 instead of "pasztet". However, the difference lies in stuffing that "pasztet" does not have. Luckily, the most accurate Polish equivalent found its place in the translation and reflects the original scene since Peter Parker is consuming the meat loaf with no filling.

A similar case refers to "organic eggs" (00:55:07) translated into "jaja z wolnego chowu". Also here, the translator resists the temptation to employ a literal translation "organiczne". The Polish equivalent is more common and well-known to a Polish consumer. Therefore, it is another example of adapting the SC to the needs of the target viewer.

It is debatable whether the last film analyzed in this article is a superhero film. The vulgar language and violence make it look like a blood and gore film. Deadpool, which

${ }^{13}$ https://dictionary.cambridge.org/dictionary/english/theatrics [access: 20.09.2021].

14 Ibidem..

15 https://www.diki.pl/slownik-angielskiego?q=meat+loaf, https://translate.google. $\mathrm{pl} /$ ?hl=en $\& \mathrm{tab}=\mathrm{wT} \& \mathrm{sl}=\mathrm{en} \& \mathrm{tl}=\mathrm{pl} \&$ text $=$ meat $\% 201$ oaf $\&$ op $=$ translate $[$ access: 21.09 .2021$]$. 
is to be discussed here, is controversial and its translation mainly focuses on the SL. Nevertheless, there are plenty examples of cultural modifications and another instance of "pasztet".

\begin{tabular}{|l|l|}
\hline ST $(00: 29: 41-00: 29: 44)$ & TT \\
\hline $\begin{array}{l}\text { Yeah, time to undo what you did } \\
\text { to this butterface. }\end{array}$ & $\begin{array}{l}\text { Czas odpicować } \\
\text { ten pasztet. }\end{array}$ \\
\hline
\end{tabular}

This time the noun "pasztet" has a different meaning, not related to food as it denotes an unattractive person. It mirrors the original "butterface" as Deadpool's face is badly deformed causing irreversible change in his look. The translator employs the adaptation strategy which sounds accurate in the TL and equally funny.

Another dialogue exemplifies different monetary system that cannot be directly rendered in the TL. Deadpool says:

\begin{tabular}{|l|l|}
\hline ST $(00: 16: 02-00: 16: 06)$ & TT \\
\hline Jeremy, I belong to a group of guys & Jeremy, należę do tych, \\
who take a dime & którzy spraliby kogoś \\
to beat a fellow down. & za garść drobniaków. \\
\hline
\end{tabular}

The visible discrepancy between ST and TT refers to the noun "dime" that is understood as "a coin that has the value of ten cents" ". Along with penny, nickel and a quarter, dime is a common coin in the United States of America and Canada. Translating the noun into "dziesięciocentówka" would be more accurate but a viewer does not seek accuracy. The main emphasis should be put on natural language that reflects casual or even vulgar register as this is the way the main character expresses himself. Therefore, "garść drobniaków", though more descriptive, matches the context and makes the whole utterance more understandable to a target viewer.

There is also one more example illustrating a different method of translating a name of a coin.

\begin{tabular}{|l|l|}
\hline ST $(00: 30: 31-00: 30: 32)$ & TT \\
\hline God, if I had a nickel for $[\ldots]$ & Gdyby placili mi za $[\ldots]$ \\
\hline
\end{tabular}

Unlike "dime" being rendered into "drobniaki", in this case the translator does not attempt to give a close equivalent to the SL. A nickel, which is worth five cents, is paraphrased into a verb "płacić". Similarly to the above example, the viewer does not hear "pięciocentówka" in Deadpool's utterance. The target text proves to be natural and accessible as the SC element is modulated and adapted to the culture of the Polish viewer.

\footnotetext{
${ }^{16}$ https://dictionary.cambridge.org/dictionary/english/dime [access: 20.09.2021].
} 
There are also other complicated culture-bound elements to render. Local measurements would be a good example to illustrate translator's choices. Deadpool utters:

\begin{tabular}{|l|l|}
\hline ST $(00: 34: 42-00: 34: 44)$ & TT \\
\hline We're within $\mathbf{5 0 0}$ yards of a school. & Szkoła jest pól kilometra stąd. \\
\hline
\end{tabular}

"Yard" is a British and American "a unit for measuring length, equal to 3 feet (36 inches) or 0.9144 of a meter" $"$. If one wish to do the math, the evident unit conversion points to $0.4572 \mathrm{~km}$, which in round numbers gives $0.5 \mathrm{~km}$, hence the Polish translation - "pó1 kilometra". The translator employs covert translation ${ }^{18}$, so that the viewer does not feel any cultural and language barriers. Instead, s/he can rely on Polish measurement and the necessity to visualize the distance is no longer problematic.

Dissimilar names of TV programs and the form of them entails another translation difficulty. This obstacle is present in Deadpool's utterance:

\begin{tabular}{|l|l|}
\hline ST (00:34:14 - 00:34:19) & TT \\
\hline I'd say that you sound like an infomercial, & Trąci reklamą z telezakupów \\
but not a good one, & I to taką kiepską \\
like Slap Chop. & -- \\
More Shake Weight-y. & jak trzęsących hantli. \\
\hline
\end{tabular}

"Informercial" is "a long television advertisement, that contains a lot of information and seems like a normal program"19. This noun has its closest counterpart in Polish as the translator decides to employ "telezakupy". The translation is accurate and focuses on the target culture. If the translator wanted to use a different equivalent, s/he would need to think of a more descriptive phrase "reklama informacyjna" which is a good definition but definitely artificial one, not corresponding to the character's way of formulating his thoughts. "Slap Chop" is the part that was omitted. Knowing that it refers to "a manual chopper machine that chops food when you slap the plunger" ${ }^{20}$, the possible equivalent could be "siekacz do warzyw". At this point, it needs to be verified which word or phrase is indispensable and contributes to the scene. Rightfully, the translator decides not to include "Slap Chop" in the TT. Unlike the device, "Shake Weight" is explained instead of being accurately rendered. This dumbbell, which has been modified to shake, has its closest counterpart - "trzęsące hantle", which reveals its purpose and function. The name of the product is not popular in Poland, which could be the reason the translator decides not to use it in unchanged form.

The last example refers to the event that is celebrated differently in North America and Poland. Deadpool's worst enemy, Ajax, provokes him by making fun of his deformed face.

\footnotetext{
${ }^{17} \mathrm{https}$ ://www.oxfordlearnersdictionaries.com/definition/english/yard?q=yard [access: 20.09.2021].

18 House J., 2009, Translation, Oxford: Oxford University Press

19 https://dictionary.cambridge.org/dictionary/english/infomercial [access: 20.09.2021].

${ }^{20}$ https://www.slapchop.com [access: 20.09.2021].
} 


\begin{tabular}{|l|l|}
\hline ST $(00: 50: 16-00: 50: 21)$ & TT \\
\hline $\begin{array}{l}\text { Looks like someone lost his } \\
\text { shot at Homecoming King. }\end{array}$ & Królem studniówki \\
już nie zostaniesz.
\end{tabular}

"Homecoming" is the tradition in the United States and Canada of welcoming back former students and members and celebrating an organization's existence ${ }^{21}$. It is celebrated at school or college and involves dancing. In contrast to the event held after graduation, "studniówka" is organized in high schools about a hundred days before school-leaving final exams. Thus, the moment of celebration differs. If a different counterpart were to be sought, the possible translation could be "bal absolwentów". The only difference lies in the popularity of the event. "Studniówka" is organized at almost every high school as an important part of school life. On the other hand, "Bal absolwentów" is a social reunion but held far less frequently. Years back, choosing a King and a Queen of the ball was not common. Nevertheless, this celebration is getting more and more popular due to the disturbing tendency to Americanize Polish language and customs. The translator's choice to render this scene is adequate and aims at a target viewer and his/her culture.

\section{Conclusions}

Untranslatability mainly refers to the difficulty, or even inability to translate texts, which is caused by discrepancies between two dissimilar language systems and cultures. In the article, only elements rooted in the source culture were analyzed. All language differences were not examined as the Author intended to show creative ideas of rendering the source culture elements so that the main attention is focused on the target viewer and TC.

The analyzed movie fragments show that Thor: Ragnarok and Deadpool contain the greatest number of examples of adaptation. This strategy brings a lot of benefits as the TT becomes even more humorous and more appreciated by the target viewers. Needless to say, there were utterances translated quite literally but the overall tone and the source message were preserved. Not every culture-bound element needs to be adapted in the TC as there are also a lot of similarities between Polish and American cultures and in certain cases a mere explanation can be added to the translation to dissolve all doubts and make the TT less ambiguous. Viewers appreciate the AVT of the two movies and they consider both films funny and entertaining, giving Thor: Ragnarok 7.8 stars (out of 10) and Deadpool 7.6 stars $^{22}$.

The other two movies, Green Lantern and The Amazing Spider-Man, are scored lower: Green Lantern got 5.6/10 and The Amazing Spider-Man 6.7/1023. The lower score has very little to do with a film budget as Deadpool had $\$ 58$ million budget ${ }^{24}$, whereas The

\footnotetext{
${ }^{21}$ https://en.wikipedia.org/wiki/Homecoming [access: 20.09.2021].

${ }^{22}$ www.filmweb.pl [access: 20.09.2021].

23 Ibidem.

${ }^{24}$ https://en.wikipedia.org/wiki/Deadpool_(film) [access: 20.09.2021].
} 
Amazing Spider-Man got \$230 million budget ${ }^{25}$. Therefore, the essential part governing positive evaluation needs to be mainly connected with the plot and dialogues. AV translators have a very responsible job. They are to save or ruin the film. They can even enhance the humorous effect by adapting target culture elements when necessary or advisable. The subjective opinion as what to do with the language and how to overcome obstacles belongs to them.

It is debatable whether dubbing is an honorable method to mirror the original film. There are voices of criticism claiming that the charm of the film, the unique voices of the actors and the overall effect of the movie are lost. However, it should be noticed that this mode of AVT is the most expensive one and simultaneously, the best for children watching animated movies. With limitations unavoidable in subtitles, only voice-over is similar in terms of accuracy. Regardless of the AVT mode, there is only one, the most important criterion - to enable a target viewer to experience similar emotions while watching a film. The emotions will never by identical as source and target cultures differ, but with the use of adaptation technique the final effect can surpass expectations.

\section{Bibliography}

Fawcett P., 1997, Translation and Language: Linguistic Theories Explained, Manchester, UK: St. Jerome Publishing.

Hejwowski K., 2009, Kognitywno-komunikacyjna teoria przekładu, Warszawa: PWN.

House J., 2009, Translation, Oxford: Oxford University Press.

Vinay J. and Darbelnet J., 2000, Stylistique comparée du français et de l'anglais. Méthode de traduction (Comparative Stylistics of French and English. Methodology for Translation), Paris: Didier.

Wojtasiewicz O., 1957, Wstęp do teorii ttumaczenia, Wrocław: Zakład Imienia Ossolińskich.

\section{Internet Sources:}

https://pl.wikipedia.org/wiki/Kawa\#Kawa_w Polsce [access: 19.09.2021].

https://www.imdb.com/title/tt0102685/ [access: 19.09.2021].

https://dictionary.cambridge.org/dictionary/english/theatrics [access: 20.09.2021].

https://dictionary.cambridge.org/dictionary/english/dime [access: 20.09.2021].

https://www.oxfordlearnersdictionaries.com/definition/english/yard?q=yard [access: 20.09.2021].

https://dictionary.cambridge.org/dictionary/english/infomercial [access: 20.09.2021].

https://www.slapchop.com [access: 20.09.2021].

https://en.wikipedia.org/wiki/Homecoming [access: 20.09.2021].

${ }^{25}$ https://en.wikipedia.org/wiki/The_Amazing_Spider-Man_(film) [access: 20.09.2021]. 
www.filmweb.pl [access: 20.09.2021].

https://en.wikipedia.org/wiki/Deadpool_film) [access: 20.09.2021].

https://en.wikipedia.org/wiki/The_Amazing_Spider-Man_film) [access: 20.09.2021].

https://www.cda.pl/video/380312824 [access: 20.09.2021].

https://www.diki.pl/slownik-angielskiego?q=meat+loaf [access: 21.09.2021].

https://translate.google.pl/?hl=en\&tab=wT\&sl=en\&tl=pl\&text=meat\%20loaf\&op=translate [access: 21.09.2021].

\section{Streszczenie}

\section{(Nie)przekładalność kulturowa w tłumaczeniach audiowizualnych}

Autorka artykułu skupia się na dwóch technikach thumaczenia audiowizualnego - dubbingu i filmie z lektorem. Celem pracy jest obalenie mitu o absolutnej nieprzekładalności kulturowej, zaś badaniom zostały poddane fragmenty filmów o superbohaterach. Tłumacz audiowizualny musi stawić czoło wielu wyzwaniom, jednakże strategie stosowane do przekładów tekstów nacechowanych kulturowo są pomocne, a wręcz niezbędne w procesie przekładu. Jedną z takich strategii jest adaptacja, która jest efektywna i przyczynia się do pozytywnego odbioru filmu przez widza docelowego. Właściwa interpretacja fragmentów kulturowych warunkuje przystępność języka i może przyczynić się do wzmocnienia efektu humorystycznego w polskiej wersji językowej. Analizowane przykłady pokazują, że tłumacze wykazali się kreatywnością, a ich wybory translatorskie nierzadko były zaskakujące, co zostało docenione przez odbiorców.

Słowa kluczowe: nieprzekładalność, kultura źródłowa, kultura docelowa, przekład audiowizualny, adaptacja 